\title{
Bahan Ajar Sains Terpadu Tematik untuk Meningkatkan Kecerdasan Kuantum dan Literasi Saintifik Siswa SMP Kelas VIII
}

Diterima 27 Maret 2018, Disetujui 2 April 2018, Dipublikasikan April 2018

\author{
E Afradisca $1^{1, \mathrm{a})}$, Asrizal $^{1, \mathrm{~b})}$, dan Yurnetti ${ }^{2, \mathrm{c})}$ \\ ${ }^{1}$ Jurusan Fisika FMIPA Universitas Negeri Padang. Jl. Prof. Dr. Hamka, Air Tawar, \\ Padang, Indonesia \\ ${ }^{2}$ Jurusan Pendidikan IPA FMIPA Universitas Negeri Padang. Jl. Prof. Dr. Hamka, Air \\ Tawar, Padang, Indonesia \\ Email: \\ a)elfa.afradisca@yahoo.co.id, b)asrizal@fmipa.unp.ac.id, ${ }^{\text {c)} y u r d i a n @ f m i p a . u n p . a c . i d ~}$
}

\begin{abstract}
Abstrak. Pembelajaran sains di SMP harus diterapkan secara terpadu sehingga dapat meningkatkan wawasan dan kecerdasan siswa. Salah satu usaha untuk menjawab tantangan di atas, perlu diusahakan pengemasan materi sains dengan memperhatikan harapan tersebut. Oleh sebab itu penelitian ini berorientasi kepada pengembangan bahan ajar IPA terpadu tematik yang tujuannya adalah untuk meningkatkan kecerdasan kuantum dan literasi saintifik siswa di SMP. Jenis penelitian ini adalah penelitian dan pengembangan $(R \& D)$, dan konsep yang dikembangkan adalah "Tekanan dan Aplikasinya dalam Kehidupan Sehari-hari". Teknik penelitian R\&D yang digunakan terdiri dari sepuluh langkah, namun pada penelitian mencakup tujuh langkah yaitu: 1) mengenal potensi dan masalah, 2) mengumpulkan informasi, 3) desain produk, 4) validasi produk, 5) revisi produk, 6) uji coba produk dan 7) revisi produk. Produk penelitian divalidasi oleh dosen, guru dan dicobakan kepada siswa SMP N 31 Padang. Hasil analisis mencakup analisis validitas, praktikalitas, dan efektivitas. Hasil analisis memperlihatkan bahwa produk penelitian ini berada pada kategori valid, praktis, dan efektif digunakan dalam pembelajaran IPA di SMP. Di samping itu, bahan ajar produk penelitian ini secara efektif dapat meningkatkan kecerdasan kuantum siswa.
\end{abstract}

Kata kunci: Pengembangan, Sains terpadu, Tematik, Kecerdasan kuantum

\section{Pendahuluan}

Kurikulum 2013 mata pelajaran IPA di SMP menekankan penerapan konsep keterpaduan dalam pembelajaran IPA. diterapkan secara terpadu. Ruang lingkup materi IPA mencakup pengetahuan, keterampilan, sikap dan nilai yang dirumuskan dalam kompetensi dasar IPA yang harus dimiliki peserta didik. Pada kurikulum 2013 aspek Fisika, Kimia, dan Biologi telah terintegrasi dalam mata pelajaran IPA. Namun kenyataan yang terjadi di lapangan belum sesuai dengan yang diharapkan. Hal ini dibuktikan dari hasil studi awal yang dilakukan di tiga SMP Negeri di kota Padang yang telah menerapkan kurikulum 2013 yaitu SMPN 8 Padang, SMPN 12 Padang, SMPN 31 Padang. Ada empat studi awal yang dilakukan yaitu wawancara yang dilakukan dengan enam orang guru IPA, hasil analisis buku IPA terpadu, hasil ujian tengah semester siswa, dan hasil tes literasi saintifik siswa masing-masing sekolah.

Studi awal pertama adalah hasil wawancara dengan enam orang guru IPA. Wawancara dilakukan menggunakan lembar wawancara. Komponen dari wawancara mencakup penerapan pembelajaran IPA terpadu dan integrasi dalam bahan ajar di sekolah. Berdasarkan wawancara yang dilakukan terhadap guru IPA pada tiga sekolah diperoleh beberapa gambaran kenyataan. Pertama, guru berpendapat bahwa pembelajaran IPA terpadu bagus untuk diterapkan namun terdapat kesulitan karena latar belakang guru yang bukan berasal dari IPA. Kedua, permasalahan yang dihadapi dalam 
Sekretariat: Jurusan Pendidikan IPA, Fakultas Matematika dan Ilmu Pengetahuan Alam, Universitas Negeri Padang - Jl. Prof. Dr. Hamka, Air Tawar Padang, Sumatera Barat

E-mail :prodiipa16@gmail.com, Halaman website : http://www.semesta.ppj.unp.ac.id/index.php/semesta.

Jurnal SEMESTA, Vol.01, No.01, 2017 pp. 18-28

pelaksanaan pembelajaran IPA terpadu lebih kepada penguasaan materi. Ketiga, pembelajaran IPA di sekolah hanya berdasarkan buku cetak pegangangan guru dan siswa yang dibagikan dari Diknas saja. Keempat, siswa masih kesulitan mengaitkan konsep pelajaran dengan aplikasi kehidupan sehari-hari dan sekolah tersebut belum melakukan penilaian literasi.

Studi awal kedua adalah hasil analisis lima buku IPA yang dapat digunakan untuk mendukung pembelajaran IPA. Penilaian keterpaduan dilakukan dengan mengisi lembar penilaian dokumen. Penilaian keterpaduan dalam buku IPA ini dinilai berdasarkan kriteria keterpaduan materi Fisika, Biologi, Kimia, dan penerapannya. Kriteria penilaian ini menghasilkan Penyajian materi Biologi $37,18 \%$, Fisika 32,76\%, Kimia 23,32\% dan IPA terpadu 6,66\%. Rata-rata keterpaduan dari kelima buku IPA yang dianalisis adalah 51,6. Tingkat keterpaduan buku IPA berdasarkan analisis penilaian keterpaduan tersebut dapat dikatakan masih rendah.

Studi awal ketiga adalah hasil tes literasi saintifik siswa. Dari tes literasi yang telah dilakukan ditiga sekolah di kota Padang didapatkan rata-rata nilai tes ketiga sekolah sebesar 29,18. Dari nilai ini dapat dikemukakan bahwa tingkat literasi saintifik siswa berada pada kategori rendah.

Studi awal terakhir adalah hasil ujian tengah semester siswa. Hasil ujian tengah semester ini digunakan untuk melihat kompetensi siswa pada tingkat intelektual. Dari hasil ujian tengah semester siswa pada masing-masing sekolah didapatkan nilai rata-rata ujian tengah semester siswa adalah $56,34,83,81$, dan 47,9. Nilai rata-rata ujian tengah semester siswa ketiga sekolah adalah 62,68 . Nilai rata-rata menunjukkan bahwa masih perlu dilakukan upaya untuk meningkatkan kecerdasan intelektual siswa.

Berdasarkan hasil studi awal yang telah dilakukan di tiga sekolah di kota Padang ternyata pembelajaran IPA belum sesuai dengan kondisi ideal yang diharapkan. Pembelajaran IPA yang diharapkan dapat diterapkan secara terpadu. Sebagai solusi dari permasalahan ini adalah membuat bahan ajar IPA terpadu yang dapat meningkatkan kecerdasan kuantum dan literasi saintifik. Proses pembelajaran dapat didukung dengan beberapa sumber belajar. Pembelajaran merupakan aktivitas individu siswa dan adanya lingkungan yang dikondisikan secara khusus untuk mengarahkan aktivitas siswa (Deni, 2011). Aktivitas siswa dapat dilakukan berdasarkan aktivitas yang termuat dalam bahan ajar. Bahan ajar merupakan faktor yang mampu mendorong motivasi siswa untuk belajar yang tersusun secara sistemasis.

IPA merupakan proses yang dipergunakan untuk mempelajari objek studi, menemukan dan mengembangkan produk-produk sains, dan sebagai aplikasi, teori-teori IPA akan melahirkan teknologi yang dapat memberi kemudahan bagi kehidupan. Proses penemuan dalam pembelajaran IPA dapat dilakukan dengan eksperimen. Sesuai dengan tujuan pendidikan yang meliputi 3 aspek, yaitu mengembangkan pengetahuan, menanamkan sikap ilmiah, dan melatih keterampilan.

Literasi saintifik yaitu suatu ilmu pengetahuan dan pemahaman mengenai konsep dan proses IPA yang akan memungkinkan seseorang untuk membuat suatu keputusan dengan pengetahuan yang dimilikinya (Zuriyani, 2011). Literasi saintifik sebagai istilah dari pendekatan ilmiah, yang mana fakta dan keterampilan adalah yang terpenting, termasuk juga persoalan di samping pembelajaran, literasi saintifik membutuhkan pemecahan masalah yang mencakup dalam membuat suatu keputusan, dan literasi saintifik memungkinkan setiap orang secara efektif menerapkan pengetahuan dalam kehidupan (Jack, H., 2009).

Literasi saintifik terdiri dari tiga dimensi. Pertama, pengetahuan ilmiah atau konsep-konsep ilmiah merupakan kajian yang membantu memahami fenomena terkait. Kedua, proses ilmiah yang berpusat pada kemampuan siswa untuk memperoleh, menafsirkan dan bertindak berdasarkan bukti. Ketiga, situasi dan konteks yang berhubungan dengan penerapan pengetahuan ilmiah dan penggunaan terapan ilmiah (Utami, B., 2016). Dengan demikian melalui literasi saintifik dapat menambah pemahaman dan penerapan IPA ke dalam kehidupan sehari-hari.

Bahan ajar IPA terpadu tema pemanfaatan tekanan dalam kehidupan dibuat berdasarkan unsur-unsur dalam pengembangkan bahan ajar yang sudah ditentukan. Bahan ajar IPA terpadu tema pemanfaatan tekanan dalam kehidupan terdiri dari beberapa unsur diantaranya adalah petunjuk belajar, kompetensi yang akan dicapai, isi materi pembelajaran, informasi pendukung, latiham-latihan, lember kerja, evaluasi, respon atau balikan (Depdiknas, 2008). 
Sekretariat: Jurusan Pendidikan IPA, Fakultas Matematika dan Ilmu Pengetahuan Alam, Universitas Negeri Padang - Jl. Prof. Dr. Hamka, Air Tawar Padang, Sumatera Barat

E-mail :prodiipa16@gmail.com, Halaman website : http://www.semesta.ppj.unp.ac.id/index.php/semesta.

Jurnal SEMESTA, Vol.01, No.01, 2017 pp. 18-28

Bahan ajar IPA terpadu tema pemanfaatan tekanan dalam kehidupan memiliki beberapa keunggulan. Pertama, dengan bahan ajar IPA terpadu ini dapat mengasah kecerdasan intelektual, kecerdasan emosional, dan kecerdasan spiritual serta literasi saintifik siswa secara seimbang. Kedua, siswa memiliki kemampuan untuk menjelaskan dan memprediksi fenomena alam. Ketiga, siswa peduli terhadap lingkungan sekitar. Keempat, bahan ajar membantu dalam pelaksanaan pembelajaran IPA yang terpadu.

Penelitian terdahulu tentang pembuatan bahan ajar IPA terpadu telah dilakukan oleh Radhitaningrum (2013) yang menunjukkan bahwa Bahan ajar IPA Terpadu yang telah dikembangkan memenuhi kriteria sangat baik pada aspek bahasa dan gambar, dan baik pada aspek kelayakan isi, penyajian, dan kegrafisan. Penelitian yang dilakukan oleh Amaliya (2013) yang menunjukkan bahwa bahan ajar IPA terpadu adalah valid, praktis dan efektif. Penelitian yang telah dilakuakan oleh Asrizal (2014) menunjukkan bahwa bahan ajar IPA terpadu adalah efektif untuk meningkatkan hasil belajar ranah kognitif dan nilai karakter siswa kelas VIII SMP.

Berdasarkan latar belakang masalah yang telah diuraikan, peneliti tertarik untuk mendesain dan membuat bahan ajar IPA terpadu yang dapat digunakan dalam pembelajaran IPA SMP kelas VIII untuk meningkatkan kecerdasan kuantum dan literasi saintifik siswa. Pengumpulan data penelitian ini menggunakan lembar valiasi, lembar praktikalitas, dan lembar efektivitas. Penelitian yang dilakukan bertujuan untuk menghasilkan bahan ajar IPA terpadu tema pemanfaatan tekanan dalam kehidupan yang valid serta menentukan kepraktisan dan keefektifan penggunaan bahan ajar IPA terpadu tema pemanfaatan tekanan dalam kehidupan untuk meningkatkan kecerdasan kuantum dan literasi saintifik siswa SMP kelas VIII.

\section{Metode Penelitian}

Pada Jenis penelitian yang akan dilakukan adalah penelitian dan pengembangan (Research and Development atau R\&D). R\&D merupakan suatu metode penelitian yang digunakan untuk menghasilkan produk tertentu dan menguji keefektifan produk tersebut (Sugiyono, 2012). Produk tersebut dapat berupa bahan ajar cetak dan non cetak. Penelitian dilakukan dengan cara membandingkan keadaan sebelum diberikan perlakuan berupa bahan ajar IPA terpadu tema pemanfaatan tekanan dalam kehidupan dan keadaan sesudah diberi perlakuan. Objek penelitian adalah bahan ajar IPA terpadu tema pemanfaatan tekanan dalam kehidupan.

Penelitian R\&D terdiri dari sepuluh langkah. Namun, pada penelitian ini hanya dilakukan sampai langkah ketujuh. Ketujuh langkah penelitian R\&D meliputi: 1) mengenal potensi dan masalah, 2) mengumpulkan informasi, 3) desain produk, 4) validasi produk, 5) revisi produk, 6) uji coba produk dan 7) revisi produk.

Produk yang dihasilkan melalui penelitian R\&D dapat meningkatkan aktivitas pembelajaran IPA. Dalam penelitian ini produk yang dikembangkan adalah bahan ajar IPA terpadu tema pemanfaatan tekanan dalam kehidupan. Produk ini didesain dan dibuat bertujuan untuk meningkatkan kecerdasan kuantum dan literasi saintifik siswa SMP kelas VIII.

Bahan ajar IPA terpadu tema pemanfaatan tekanan dalam kehidupan dibuat sesuai dengan desain yang telah disusun. Desain bahan ajar IPA terpadu tema pemanfaatan tekanan dalam kehidupan terdiri dari bagian cover yang merupakan halaman depan dari bahan ajar IPA terpadu tema pemanfaatan dalam kehidupan dan bagian bahan ajar IPA terpadu yang meliputi: petunjuk belajar, kompetensi yang akan dicapai, materi pembelajaran informasi pendukung, latihan-latihan (yang berisi konsep santifik), lembar kerja (yang berisi proses saintifik, konteks saintifik, kecerdasan spiritual, dan kecerdasan emosional), evaluasi, Respon.

Bahan ajar IPA terpadu ini divalidasi oleh 5 orang dosen yang terdiri 3 orang dosen Fisika, 1 orang dosen Kimia, dan 1 orang dosen Biologi. Tahapan validasi produk dilakukan untuk mengetahui kelemahan-kelemahan yang terdapat dalam bahan ajar IPA terpadu tema pemanfaatan tekanan dalam kehidupan. Kemudian kelemahan-kelamahan tersebut direvisi oleh peneliti sebelum dilakukan ujicoba produk. Ujicoba produk dilakukan di kelas VIII.5 SMPN 31 Padang dengan jumlah siswa sebanyak 31 orang. Langkah penelitian terakhir adalah revisi produk terhadap kelemahan-kelemahn yang ditemukan pada saat dilakukan ujicoba. 
Sekretariat: Jurusan Pendidikan IPA, Fakultas Matematika dan Ilmu Pengetahuan Alam, Universitas Negeri Padang - Jl. Prof. Dr. Hamka, Air Tawar Padang, Sumatera Barat

E-mail :prodiipa16@gmail.com, Halaman website : http://www.semesta.ppj.unp.ac.id/index.php/semesta.

Jurnal SEMESTA, Vol.01, No.01, 2017 pp. 18-28

Pada penelitian ini digunakan tiga macam teknik analisis data, yaitu analisis validasi dan analisis kepraktisan yang menggunakan skala likert yang dikonversi menjadi rentangan 1 sampai 5 dan analisis keefektifan. Hasil penilaian validasi bahan ajar IPA terpadu tema pemanfaatan tekanan dalam kehidupan digambarkan dalam bentuk grafik. Perolehan bobot dihitung dengan cara mengalikan jumlah poin yang diberikan responden dengan nilai untuk responden tersebut.

Kepraktisan bahan ajar IPA terpadu dilakukan dengan pengisian lembar praktikalitas bahan ajar IPA terpadu oleh guru IPA dan siswa. Analisis penilaian kepraktisan dinyatakan dengan statistik deskriptif berupa grafik. Pembobotan skor praktikalitas dilakukan berdasarkan skala likert sama seperti hasil penilaian validasi. Bahan ajar IPA terpadu tema pemanfaatan tekanan dalam kehidupan memenuhi kategori praktis apabila diperoleh pembobotan skor 61-100.

Efektivitas bahan ajar IPA terpadu tema pemanfaatan tekanan dalam kehidupan ditentukan dari lembar penilaian kecerdasan kuantum dan lembar penilaian literasi saintifik. Kecerdasan kuantum yang dinilai adalah kecerdasan intektual berupa tes hasil belajar siswa yang dilakukan dengan pemberian pretes dan postes kepada 31 orang siswa, kecerdasan emosional siswa yang dilakukan dengan mengamati sikap emosional siswa sebelum dan sesudah diberi perlakuan berupa bahan ajar IPA terpadu tema pemanfaatan tekanan dalam kehidupan, kecerdasan spiritual siswa yang dilakukan melalui lembar penilaian tugas refleksi. Literasi saintifik yang dinilai dalam analisis efektivitas terdiri dari tiga dimensi yaitu konsep saintifik, proses saintifik dan konteks saintifik. Analisis dilakukan dengan membandingkan nilai kecerdasan kuantum dan literasi saintifik siswa pada saat sebelum dan sesudah penggunaan bahan ajar IPA terpadu tema pemanfaatan tekanan dalam kehidupan.

Analisis keefektifan bahan ajar IPA terpadu dilakukan dengan melakukan uji t. Berdasarkan hasil analisis akan diketahui sejauh mana bahan ajar IPA terpadu tema pemanfaatan tekanan dalam kehidupan dapat meningkatkan kecerdasan kuantum dan literasi saintifik untuk siswa IPA SMP kelas VIII.

\section{Hasil dan Pembahasan}

\subsection{Hasil Penelitian}

Pada penelitian ini terdapat dua hasil penelitian. Pertama, hasil uji validasi bahan ajar IPA terpadu tema pemanfaatan teknanan dalam kehidupan untuk meningkatkan kecerdasan kuantum dan literasi saintifik. Kedua, hasil uji praktikalitas dan efektivitas bahan ajar IPA terpadu tema pemanfaatan teknanan dalam kehidupan untuk meningkatkan kecerdasan kuantum dan literasi saintifik.

Hasil pertama adalah hasil validasi bahan ajar IPA terpadu tema pemanfaatan tekanan dalam kehidupan yang telah divalidasi oleh lima orang tenaga ahli. Instrumen yang digunakan adalah lembar penilaian validasi yang terdiri dari enam komponen penilaian diantaranya adalah: 1) kelayakan isi, 2) kelayakan kontruksi, 3) komponen keterpaduan, 4) kelayakan bahasa, 5) kelayakan tampilan bahan ajar, 6) kelayakan pengintegrasian literasi saintifik dalam bahan ajar. Rata-rata hasil penilaian keenam komponen penilain validasi dapat dinyatakan pada Gambar 1 .

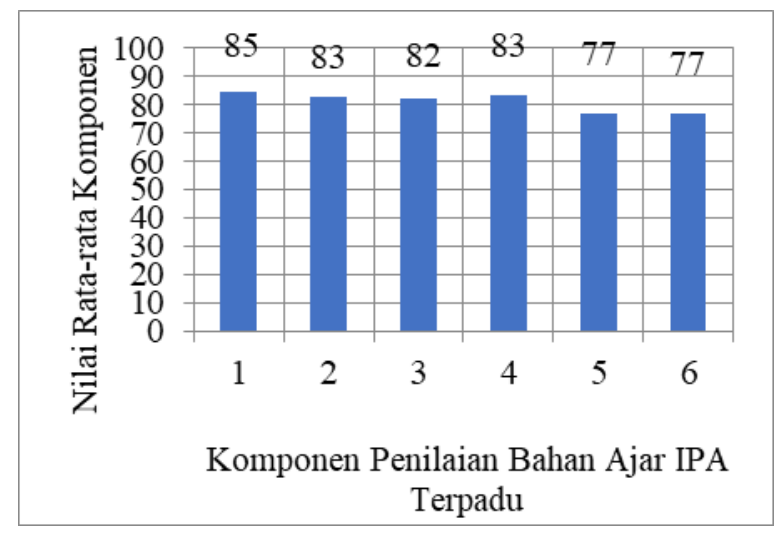


Sekretariat: Jurusan Pendidikan IPA, Fakultas Matematika dan Ilmu Pengetahuan Alam, Universitas Negeri Padang - Jl. Prof. Dr. Hamka, Air Tawar Padang, Sumatera Barat

E-mail :prodiipa16@gmail.com, Halaman website : http://www.semesta.ppj.unp.ac.id/index.php/semesta.

Jurnal SEMESTA, Vol.01, No.01, 2017 pp. 18-28

\section{Gambar 1. Penilaian Bahan Ajar IPA Terpadu}

Gambar 1 menunjukkan bahwa rentangan nilai pada hasil penilaian validasi bahan ajar IPA terpadu berada pada rentangan nilai 76,8 sampai 84,8. Pada rentangan nilai tersebut artinya bahan ajar berada pada kategori valid dan sangat valid. Nilai rata-rata dari penilaian validasi bahan ajar IPA terpadu ini adalah 81,1. Hal ini menunjukkan bahwa bahan ajar IPA terpadu meningkatkan kecerdasan kuantum dan literasi saintifik ini adalah sangat valid.

Selain memberikan penilaian validasi terhadap bahan ajar IPA terpadu tenaga ahli juga memberikan beberapa masukan untuk memperbaiki kelemahan-kelemahan pada bahan ajar IPA terpadu yang telah dibuat dan divalidasi. Masukan-masukan dari tenaga ahli tersebut kemudian direvisi oleh peneliti guna memperbaiki kelemahan-kelemahan yang ditemukan pada bahan ajar IPA terpadu tema pemanfaatan tekanan dalam kehidupan. Masukan-masukan yang diberikan oleh tenaga ahli diantaranya adalah: sebaiknya KD dan indikator diletakkan untuk setiap KD, memperhatikan fungsi layout pada bahan ajar, menjelaskan bagian kecerdasan kuantum dan literasi saintifik dalam bahan ajar, dan menambahkan kalimat penghubung kegambar.

Bahan ajar IPA terpadu terdiri dari bagian cover dan bagian bahan ajar. Cover bahan ajar IPA terpadu ini ada dua yaitu cover umum dan cover untuk masing-masing subtema. Cover umum menunjukkan identitas dan gambar yang mendukung semua subtema pada bahan ajar. Setiap subtema pada bahan ajar juga menggunakan cover yang menunjukkan identitias pada masing-masing judul subtema. Cover bahan ajar dapat dilihat pada Gambar 2.

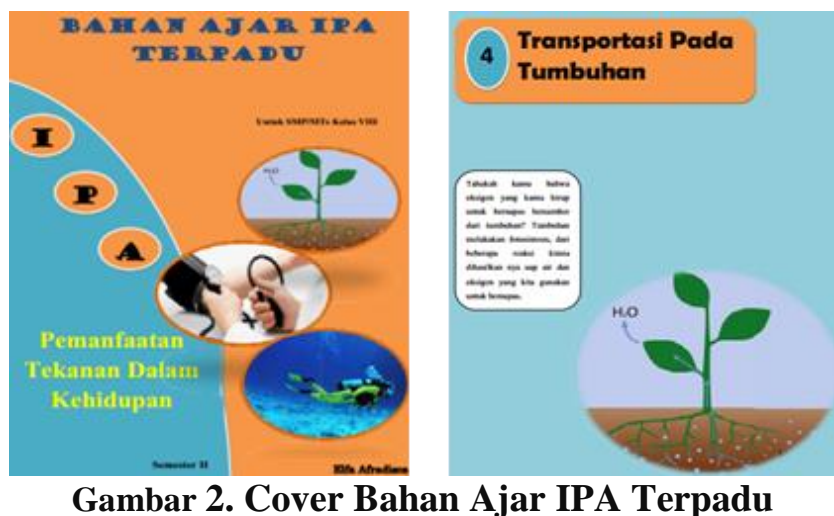

Bahan ajar IPA terpadu juga memuat kompetensi yang akan dicapai oleh siswa setelah mempelajari materi. Kompetensi yang dimuat dalam bahan ajar IPA terpadu adalah kompetensi inti dan kompetensi dasar. Kompetensi dasar (KD) yang digunakan pada bahan ajar IPA terpadu ini ada dua KD diantaranya adalah: KD 3.7 Memahami tekanan zat dan penerapannya dalam kehidupan sehari-hari, termasuk tekanan darah, osmosis, dan kapilaritas jaringan angkut pada tumbuhan. KD 3.8Menganalisis sistem peredaran darah pada manusia dan memahami gangguan pada sistem peredaran darah, serta upaya ,menjaga kesehatan sistem peredaran darah. Selain kompetensi inti dan kompetensi dasar, bahan ajar juga memuat indikator yang diturunkan dari kompetensi dasar.

Pencapaian kompetensi ini didukung dengan pemaparan materi pada bahan ajar IPA terpadu. Materi yang disajikan dalam bahan ajar IPA terpadu berdasarkan kompetensi dasar yang dipadukan kedalam satu tema. Tema dipilih mencakup keterpaduan dua kompetensi dasar yang ada dalam bahan ajar dan dekat dengan kehidupan sehari-hari. Tema bahan ajar ini terletak di tengah-tengah dan di teruskan dengan cabang-cabang subtema. Rangkaian tema dapat dilihat pada Gambar 3. 
Sekretariat: Jurusan Pendidikan IPA, Fakultas Matematika dan Ilmu Pengetahuan Alam, Universitas Negeri Padang - Jl. Prof. Dr. Hamka, Air Tawar Padang, Sumatera Barat

E-mail :prodiipa16@gmail.com, Halaman website : http://www.semesta.ppj.unp.ac.id/index.php/semesta.

Jurnal SEMESTA, Vol.01, No.01, 2017 pp. 18-28

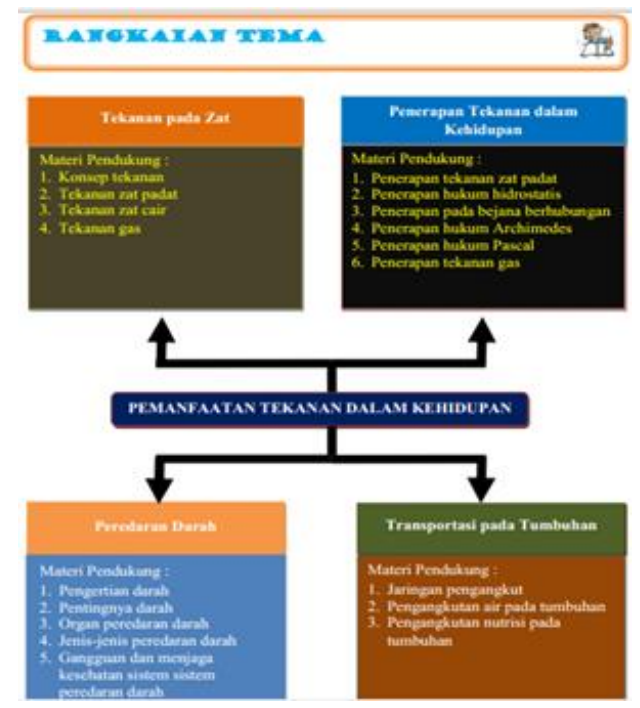

Gambar 3. Rangkaian Tema Pada Bahan Ajar

Bahan ajar ini terdiri dari empat subtema yang di padukan dengan menggunakan tema. Tema pada bahan ajar ini adalah pemanfaatan tekanan dalam kehidupan. Seubtema bahan ajar IPA terpadu terdiri dari: tekanan pada zat, penerapan tekanan pada zat, peredaran darah, dan transportasi pada tumbuhan. Tema bahan ajar IPA terpadu yang terletak di tengah merupakan paduan dari semua subtema. Subtema yang merupakan cabang-cabang dari tema mencakup materi terkait tema pada bahan ajar. Pada bahan ajar juga termuat informasi pendukung yang merupakan informasi tambahan dalam bahan ajar. Informasi tambahan ini akan menambah pengetahuan siswa terkait materi yang dipelajari. Latihan-latihan yang disajikan pada bahan ajar berfungsi meningkatkan konsep saintifik siswa dengan penemuan konsep dan fenomena terkait materi. Proses saintifik tergambarkan melalui lembar kerja yang terdapat di dalam bahan ajar. Lembar kerja ini mendukung kegiatan penyelidikan siswa dan lembar kerja lainnya seperti tugas konteks saintifik dan tugas refleksi yang juga terdapat dalam bahan ajar IPA terpadu ini. Selain itu, pada bahan ajar IPA terpadu juga terdapat komponen evaluasi. Evaluasi ini berisikan soal-soal pilihan ganda yang dapat dikerjakan siswa untuk menguji sejauh mana pengetahuan siswa terhadap materi yang ada pada bahan ajar. Evaluasi ini juga disertai respon atau balikan terhadap evaluasi.

Hasil penelitian yang kedua adalah hasil analisis kepraktisan dan efektivitas bahan ajar IPA terpadu tema pemanfaatan tekanan dalam kehidupan. Praktikalitas dilihat dari hasil penilaian kepraktisan menurut guru IPA dan siswa. Penilaian praktikalitas menurut guru dilakukan dengan instrumen praktikalitas yang diisi oleh satu orang guru IPA di SMPN 31 Padang. Instrumen praktikalitas menurut guru terdiri dari empat komponen meliputi: 1) isi bahan ajar, 2) sajian dalam bahan ajar, 3) kemudahan dalam bahan ajar, dan 4) manfaat bahan ajar. Analisis dari keempat komponen pada lembar praktikalitas guru tersebut dicantumkan pada Gambar 4. 
Sekretariat: Jurusan Pendidikan IPA, Fakultas Matematika dan Ilmu Pengetahuan Alam, Universitas Negeri Padang - Jl. Prof. Dr. Hamka, Air Tawar Padang, Sumatera Barat

E-mail :prodiipa16@gmail.com, Halaman website : http://www.semesta.ppj.unp.ac.id/index.php/semesta.

Jurnal SEMESTA, Vol.01, No.01, 2017 pp. 18-28

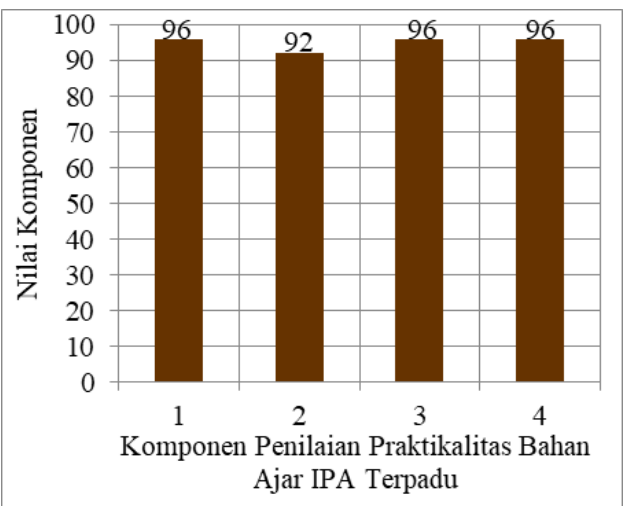

\section{Gambar 4. Komponen Praktikalitas Bahan Ajar Menurut Guru IPA}

Berdasarkan Gambar 4 penilaian kepraktisan pada masing-masing komponen ini menunjukkan nilai antara 92,0 sampai 96,0. Rentangan nilai tersebut berada pada kategori sangat praktis. Nilai ratarata yang diperoleh dari keempat indikator adalah 95,0. Oleh karena itu, dapat dinyatakan bahwa bahan ajar IPA terpadu untuk meningkatkan kecerdasan kuantum dan literasi saintifik siswa ini sangat praktis untuk digunakan dalam pemebelajara IPA terpadu.

Praktikalitas menurut siswa dapat dilakukan dengan menggunakan instrumen lembar penilaian praktikalitas berdasaran penilaian siswa. Jumlah siswa yang mengisi lembar praktikalitas ini adalah 31 orang siswa. Pada instrumen penilaian praktikalitas menurut siswa terdapat empat komponen penilaian diantaranya: 1) kemudahan dalam bahan ajar, 2) keutuhan materi, 3) motivasi dalam belajar, 4) penguasaan terhadap materi. Hasil analisis praktikalitas siswa dipaparkan pada Gambar 5.

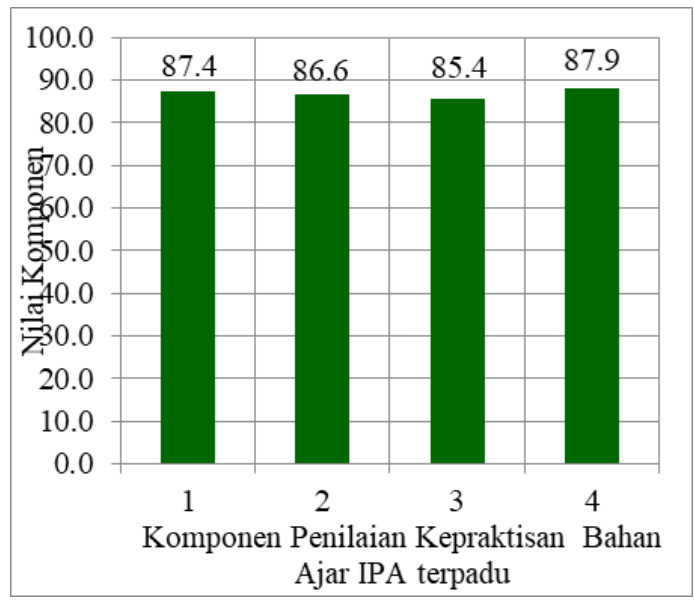

\section{Gambar 5. Penilaian Kepraktisan Bahan Ajar IPA Terpadu menurut Siswa}

Berdasarkan grafik komponen penilaian kepraktisan bahan ajar IPA terpadu menurut siswa terlihat bahwa rentangan nilai hasil plot pada grafik yaitu 85,4 sampai 87,8 . Rentangan nilai menunjukkan bahwa bahan ajar IPA terpadu untuk meningkatkan kecerdasan kuantum dan literasi saintifik adalah sangat praktis untuk digunakan siswa SMP dalam pembelajaran IPA.

Uji efektivitas pada penelitian ini meliputi hasil tes tulis kecerdasan intelektual, observasi kecerdasan emosional siswa, dan pengamatan literasi saintifik siswa serta kecerdasan spiritual dalam bentuk refleksi. Analisis data yang digunakan untuk uji efektivitas adalah rumus product moment. Untuk menentukan harga th dengan menggunakan t-test berkorelasi. Penilaian hasil tes inteklektual siswa dilihat dari hasil belajar siswa sebelum menggunakan bahan ajar IPA terpadu dan tes intelektual sesudah menggunakan bahan ajar IPA terpadu. Jumlah siswa yang mengikuti tes intelektual sebelum dan sesudah berjumlah 31 orang. Soal tes yang diberikan berjumlah 25 butir soal pilihan ganda. 
Sekretariat: Jurusan Pendidikan IPA, Fakultas Matematika dan Ilmu Pengetahuan Alam, Universitas Negeri Padang - Jl. Prof. Dr. Hamka, Air Tawar Padang, Sumatera Barat

E-mail :prodiipa16@gmail.com, Halaman website : http://www.semesta.ppj.unp.ac.id/index.php/semesta.

Jurnal SEMESTA, Vol.01, No.01, 2017 pp. 18-28

Berdasarkan analisis data terhadap nilai tes intelektual sebelum dan sesudah didapatkan nilai koefisien korelasi adalah 0,03. Sehingga didapatkan harga th adalah -16,12. Harga t_t diperoleh dengan mencari derajat kebebasan terlebih dahulu. Derajat kebebasan dicari dengan jumlah siswa yang mengikuti tes hasil belajar dikuragi satu. Jumlah siswa yang menjadi subjek penelitian berjumlah 31 orang. Derajat kebebasan (dk) adalah 30 dan harga t pada taraf signifikansi 5\% adalah 1,70 sehingga $t_{-} t=1,70$. Oleh karena $t \_h$ bernilai negatif maka digunakan uji pihak kiri sehingga harga $t \_t=-$ 1,70. Nilai t_h pada penelitian lebih kecil daripada nilai t_t. Dengan demikian bahan ajar ini sudah efektif untuk digunakan dalam pembelajaran IPA.

Pengamatan kecerdasan emosional siswa dilakukan sebelum menggunakan bahan ajar IPA terpadu dan waktu menggunakan bahan ajar IPA terpadu. Indikator kecerdasan emosional mencakup 1) rasa ingin tahu, 2) disiplin, 3) tanggung jawab, 4) kerja sama, dan 5) komunikatif. Analisis data menunjukkan bahwa korelasi kecerdasan emosional adalah 0,76 dengan th sebesar -24,89. Nilai tt dengan $\mathrm{dk}=30$ adalah $-1,70$. Nilai t_h pada analisis lebih kecil daripada nilai t_t. Hal ini berarti hipotesis kerja diterima. Artinya bahan ajar IPA terpadu tema pemanfaatan tekanan dalam kehidupan adalah efektif untuk meningkatkan kecerdasan emosional siswa SMP kelas VIII.

Penilaian kecerdasan spiritual dinilai menggunakan instrumen penilaian tugas refleksi. Melaui penilaian refleksi ini dapat dinilai tingkat kecerdasan kuantum siswa dalam hal religius dan sosialnya. Penilaian refleksi ini dilakukan sebelum dan pada waktu menggunakan bahan ajar IPA terpadu. Indikator penilaian refleksi mencakup 1) kesadaran terhadap ciptaan Allah SWT, 2) berpikir terhadap ciptaan Allah SWT, 3) bangga terhadap ciptaan Allah SWT, 4) bersyukur terhadap ciptaan Allah SWT, dan 5) hubungan dengan teman. Nilai korelasi yang didapatkan adalah 0,58 sehingga didapatkan hasil $t \_h$ adalah sebesar $-26,17$. Nilai tt dengan $\mathrm{dk}=30$ adalah $-1,70$. Nilai $t \_h$ pada penelitian lebih kecil daripada nilai t_t. Hal ini menunjukkan bahwa bahan ajar IPA terpadu tema pemanfaatan tekanan dalam kehidupan adalah efektif untuk meningkatkan kecerdasan spiritual siswa.

Penilaian literasi saintifik siswa dilakukan pada saat sebelum dan pada waktu penggunaan bahan ajar IPA terpadu. Penilaian literasi saintifik ini dapat dinilai dari konsep saintifik, proses saintifik, konteks saintifik. Nilai konsep saintifik dapat dinilai dari pemberian tugas berupa soal-soal untuk menemukan konsep-konsep dan peristiwa-peristiwa terkait dengan materi yang telah dipelajari dalam bahan ajar IPA terpadu. Penilaian terhadap konsep siswa dilakukan pada saat sebelum dan pada waktu sesudah menggunakan bahan ajar IPA terpadu. Berdasarkan analisis data penilaian konsep saintifik didapatkan korelasi sebesar 0,84 sehingga harga th adalah sebesar $-18,93$. Nilai tt dengan $\mathrm{dk}=$ 30 adalah -1,70. Nilai t_h pada penelitian lebih kecil daripada nilai t_t. Dengan demikian bahan ajar IPA terpadu tema pemanfaatan tekanan dalam kehidupan adalah efektif untuk meningkatkan konsep saintifik siswa SMP kelas VIII.

Nilai proses saintifik dinilai dari kinerja siswa penyelidikan dan hasil laporan penyelidikan. Indikator penilaian proses saintifik pada kegiatan penyelidikan mencakup 1) menyiapkan alat, 2) menyusun alat, 3) menggunakan alat, 4) mengambil data, 5) menempatkan data pada tabel, dan 6) mengembalikan alat. Analisis data menghasilkan nilai korelasi sebesar 0,84 sehingga diperoleh th adalah sebesar $-28,7$. Nilai tt dengan $\mathrm{dk}=30$ adalah $-1,70$. Nilai $\mathrm{t} \_\mathrm{h}$ pada penelitian lebih kecil daripada nilai t_t. Hal ini menunjukkan bahwa bahan ajar IPA terpadu tema pemanfaatan tekanan dalam kehidupan adalah efektif untuk meningkatkan proses saintifik dalam penyelidikan.

Nilai laporan penyelidikan juga merupakan penilaian proses literasi saintifik. Indikator penilaian laporan penyelidikan mencakup 1) tujuan penyelidikan, 2) prosedur kerja, 3) data dan pengolahan, 4) kesimpulan, dan 5) kerapian laporan. Berdasarkan analisis data nilai laporan penyelidikan siswa diperoleh korelasi sebesar 0,49. Nilai t_h adalah sebesar -25,77. Nilai tt dengan dk $=30$ adalah $-1,70$. Berdasarkan analisis data yang diperoleh dapat dilihat bahwa nilai $\mathrm{t} \_\mathrm{h}$ pada penelitian lebih kecil daripada nilai t_t sehingga hipotesis kerja diterima. Hal ini menunjukkan bahwa bahan ajar IPA terpadu tema pemanfaatan tekanan dalam kehidupan adalah efektif untuk meningkatkan proses saintifik pada laporan penyelidikan.

Penilaian konteks saintifik ini dilakukan dengan memberikan pertanyaan yang sudah ada dalam bahan ajar IPA terpadu mengenai penerapan materi yang dipelajari siswa dalam kehidupan sehari-hari. Indikator penilaian konteks saintifik mencakup 1) kerapian tulisan, 2) kelengkapan 
Sekretariat: Jurusan Pendidikan IPA, Fakultas Matematika dan Ilmu Pengetahuan Alam, Universitas Negeri Padang - Jl. Prof. Dr. Hamka, Air Tawar Padang, Sumatera Barat

E-mail :prodiipa16@gmail.com, Halaman website : http://www.semesta.ppj.unp.ac.id/index.php/semesta.

Jurnal SEMESTA, Vol.01, No.01, 2017 pp. 18-28

aplikasi, 3) kebenaran materi, 4) kesesuaian aplikasi, dan 5) referensi materi. Nilai korelasi yang didapatkan dari hasil analisis data penilaian konteks saintifik siswa adalah sebesar 0,76. Nilai t_h adalah sebesar -29,95. Nilai t_h yang didapatkan pada penelitian lebih kecil daripada nilai t_t. Dengan demikian bahan ajar IPA terpadu tema pemanfaatan tekanan dalam kehidupan adalah efektif untuk meningkatkan nilai konteks saintifik siswa.

\subsection{Pembahasan}

Berdasarkan validasi yang telah dilakukan oleh lima orang tenaga ahli, dapat dikatakan bahwa produk berupa bahan ajar cetak IPA terpadu tema pemanfaatan tekanan dalam kehidupan ini adalah valid sangat. Hal ini dibuktikan dengan nilai rata-rata validasi yang didapatkan adalah 81,14 . Suatu produk dikatakan valid apabila produk tersebut dibuat sesuai dengan struktur yang dipedomani. Bahan ajar yang baik paling tidak berisi tentang petunjuk belajar, kompetensi yang akan dicapai, content atau isi materi pembelajaran, informasi pendukung, latihan-latihan, petunjuk kerja, dapat berupa Lembar Kerja (LK), evaluasi, respon atau balikan terhadap hasil evaluasi ${ }^{[6]}$. Bahan ajar IPA terpadu tema pemanfaatan tekanan dalam kehidupan yang dihasilkan mencakup semua struktur bahan ajar yang baik tersebut sehingga bahan ajar IPA terpadu adalah valid.

Bahan ajar IPA terpadu tema pemanfaatan tekanan dalam kehidupan ini adalah praktis untuk digunakan dalam pembelajaran. Kepraktisan bahan ajar diukur dari kemudahan dan keterlaksanaannya dalam penggunaan bahan ajar. Salah satu manfaat penggunaan bahan ajar adalah peserta didik mendapatkan kemudahan dalam mempelajari setiap kompetensi yang harus dikuasainya (Prastowo, 2011).

Hasil analisis instrumen kepraktisan yang diisi guru IPA dan siswa SMP kelas VIII menunjukkan bahwa nilai rata-rata kepraktisan menurut guru IPA dan siswa masing-masing adalah 95,0 dan 86,8 . Nilai rata-rata ini berada pada kategori sangat praktis. Oleh karena itu, bahan ajar IPA terpadu tema pemanfaatan tekanan dalam kehidupan adalah praktis untuk digunakan dalam pembelajaran IPA kelas VIII di SMP.

Hasil uji keefektifan bahan ajar IPA terpadu dapat diukur pada komponen kecerdasan kuantum yang meliputi kecerdasan intelektual, emosional, dan spiritual. Serta komponen literasi saintifik yang terdiri dari konsep saintifik, proses saintifik, dan konteks saintifik. Berdasarkan hasil uji efektivitas pada penggunaan bahan ajar IPA terpadu tema pemanfaatan tekanan dalam kehidupan dalam proses pembelajaran IPA menunjukkan adanya peningkatan baik pada komponen pengetahuan, sikap dan keterampilan. Dengan demikian bahan ajar IPA terpadu tema pemanfaatan tekanan dalam kehidupan adalah efektif untuk digunakan dalam proses pembelajaran IPA kelas VIII di SMP.

Guru dapat menggunakan bahan ajar IPA terpadu tema pemanfaatan tekanan dalam kehidupan ini dapat untuk mendukung proses pembelajaran IPA terpadu di SMP kelas VIII semester 2. Bahan ajar ini memuat materi tekanan pada zat, peredaran darah, dan transportasi pada tumbuhan yang dipadukan dalam satu tema yaitu tema tekanan dalam kehidupan. Di sisi lain, siswa juga dapat menggunakan bahan ajar ini untuk menambah sumber belajar siswa dan menambah pemahaman siswa dalam proses pembelajaran IPA.

Dalam pembuatan bahan ajar IPA terpadu ini terdapat empat keterbatasan. Keterbatasan pertama adalah keterbatasan model keterpaduan hanya menggunakan model terjaring. Hal ini disebabkan hubungan antar materi dalam bahan ajar IPA terpadu dipadukan dengan sebuah tema yang dekat dengan kehidupan. Model keterpaduan yang lain masih banyak seperti model integrasi dan terhubung. Solusi untuk keterbatasan model keterpaduan ini yaitu hendaknya bisa menggunakan model keterpaduan lainnya.

Keterbatasan kedua yaitu keterbatasan materi. Materi yang dikembangkan dalam bahan ajar IPA terpadu ini hanya materi pada KD 3.7 Menganalisis sistem peredaran darah pada manusia dan memahami gangguan pada sistem peredaran darah, serta upaya menjaga kesehatan sistem peredaran darah. KD 3.8 Memahami tekanan zat dan penerapannya dalam kehidupan sehari-hari, termasuk tekanan darah, osmosis, dan kapilaritas jaringan angkut pada tumbuhan. Solusi untuk keterbatasan ini yaitu ditindak lanjuti materi pada KD selanjutnya. 
Sekretariat: Jurusan Pendidikan IPA, Fakultas Matematika dan Ilmu Pengetahuan Alam, Universitas Negeri Padang - Jl. Prof. Dr. Hamka, Air Tawar Padang, Sumatera Barat

E-mail :prodiipa16@gmail.com, Halaman website : http://www.semesta.ppj.unp.ac.id/index.php/semesta.

Jurnal SEMESTA, Vol.01, No.01, 2017 pp. 18-28

Keterbatasan ketiga yaitu keterbatasan pedoman pengembangan bahan ajar. Bahan ajar IPA terpadu tema pemanfaatan tekanan dalam kehidupan ini berpedoman pada pengembangan bahan ajar depdiknas 2008. Solusi untuk keterbatasan ini yaitu tindak lanjut pembuatan bahan ajar dengan menggunakan panduan pengembangan bahan ajar yang lain.

Keterbatasan yang terakhir adalah keterbatasan literasi. Literasi yang digunakan pada bahan ajar IPA terpadu tema pemanfaatan tekanan dalam kehidupan ini adalah literasi saintifik. Masih ada banyak literasi yang lain diantaranya literasi visual, fungsional, dan informasi. Solusi untuk keterbatasan ini adalah menindaklanjuti pembuatan bahan ajar IPA terpadu dengan menggunakan literasi yang lainnya.

\section{Kesimpulan}

Berdasarkan penelitian yang telah dilakukan di SMPN 31 Padang dan hasil penelitian yang telah dianalisis serta pembahasan yang dipaparkan dapat dikemukakan dua kesimpulan dari penelitian ini. Pertama, bahan ajar IPA terpadu tema pemanfaatan tekanan dalam kehidupan adalah valid. Nilai ratarata analisis validasi bahan ajar IPA terpadu adalah 81,14 artinya bahan ajar berada pada kategori sangat valid. Dengan demikian bahan ajar IPA terpadu tema pemanfaatan tekanan dalam kehidupan adalah valid untuk digunakan dalam pembelajaran IPA di SMP kelas VIII semester 2. Kedua, penggunaan bahan ajar IPA terpadu tema pemanfaatan tekanan dalam kehidupan ini adalah praktis untuk digunakan siswa kelas VIII dalam proses pembelajaran IPA menurut guru dan siswa dengan nilai kepraktisan adalah 95 dan 87. Nilai rata-rata praktikalitas yang diperoleh berada pada kategori sangat praktis. Selain itu, penggunaan bahan ajar IPA terpadu tema pemanfaatan tekanan dalam kehidupan adalah efektif untuk meningkatkan kecerdasan kuantum dan literasi saintifik siswa kelas VIII SMPN 31 Padang.

\section{Ucapan Terima Kasih}

Pada bagian ini, Penulis mengucapkan terima kasih kepada Bapak Asrizal dan Ibu Dra. Yurnetti, M. Pd serta seluruh staf pengajar jurusan fisika FMIPA UNP.

\section{Daftar Pustaka}

Amaliya. 2013. Pengembangan Bahan Ajar IPA Terpadu Tema Letusan Gunung Berapi Kelas VII di SMP Negeri 1 Kamal. Jurnal Pendidikan Sains e-Pensa, Volume 01 Nomor 01 Tahun 2013, 4246.

Andi Prastowo, 2011. Panduan Kreatif Membuat Bahan Ajar Inovatif. Jogjakarta: Diva Press.

Asrizal. 2014. Efektivitas Penerapan Pembelajaran Terpadu Dengan Bahan Ajar Berbasis TIK Sains Mengintegrasikan Nilai Karakter Pada Siswa SMP Negeri 8 Padang. EKSAKTA Vol. 2 Tahun XV Juli 2014.

Budi Utami. 2016. Scientific Literacy in Science Lesson. Prosiding ICTTE FKIP UNS 2015 Vol 1, Nomor 1, Januari 2016

Deni. 2011. Pembelajaran Terpadu. Bandung: Pustaka Cendekia Utama

Depdiknas 2008. Panduan Umum Pengembangan Bahan Ajar. Jakarta: Direktorat Jendral Manajemen Pendidikan Dasar dan Menengah.

Elsy Zuriyani. 2011. Literasi Sains dan Pendidikan. Jurnal Pendidikan.

Holbrook, Jack. 2009. The Meaning Of Scientific Literacy. International Journal of Environmental \& Science Education Vol. 4, No. 3, July 2009, 275-288. 
Jurnal SEMESTA, Vol.01, No.01, 2017 pp. 18-28

Radhitaningrum,dkk. 2013. Pengembangan Bahan Ajar IPA Terpadu Berbasis Salingtemas Untuk SMP Kelas VII dengan tema Ekosistem Air Tawa. Jurnal Materi dan Pembelajaran Fisika (JMPF), Volume 3 Nomor 12013 ISSN : 2089-6158

Sugiyono. 2012. Metode Penelitian Pendidikan. Bandung : Alfabeta. 